\title{
Frekuensi Pulsus dan Nafas Sapi Peranakan Ongole Pasca Beranak yang Diinfusi Povidone Iodine 1\%
}

\section{The Heart and Respiration Rate on Postpartum Ongole Crossbreed Cattle after Infusion Povidone Iodine 1\%}

\author{
Jumaryoto $^{1}$, Agung Budiyanto ${ }^{2}$, Soedarmanto Indarjulianto ${ }^{3 *}$ \\ ${ }^{1}$ Balai Besar Inseminasi Buatan, Kotak Pos 8, Ngujung, Toyomarto, Singosari, Malang, Jawa Timur \\ ${ }^{2}$ Departemen Reproduksi dan Kebidanan, Fakultas Kedokteran Hewan, Universitas Gadjah Mada, Yogyakarta, \\ ${ }^{3}$ Departemen Ilmu Penyakit Dalam, Fakultas Kedokteran Hewan, Universitas Gadjah Mada, Yogyakarta, \\ Jl. Fauna No 2, Karangmalang, Yogyakarta, 55281, Indonesia. \\ *Correponding Author, Email: indarjulianto@ugm.ac.id
}

Naskah diterima: 11 Agustus 2020, direvisi: 18 Agustus 2020, disetujui: 20 Nopember 2020

\begin{abstract}
This study aimed to determine the frequency of respiration rate and pulse rate during postpartum period on Ongole crossbreed cattle after Povidon iodine 1\% infusion. This study used 10 Ongole crossbreed (PO) cattle with normal partus and healthy, 4-9 years old and body condition score 2.5-3.5. Cattle are devided into 2 groups 1). control 2). Povidon iodine 1\% infusion. All cattle were physically examined including general condition, respiration rate and pulse rate on the 3rd day (1st week), 38th and 66th day postpartum. Group 2 cows were given povidon iodine infusion of $250 \mathrm{ml}$ on the $3 \mathrm{rd}$ day. The results showed that the respiration rate of cattle in the control group at days 3, 38 and 66 were $29 \pm 5 ; 24 \pm 0$ and $25 \pm 4$ breaths/minute and in the treatment group were $28 \pm 3 ; 22 \pm 4$ and $21 \pm 6$ breaths/minute respectively. The pulse rate in the control group at days 3,38 and 66 were $82 \pm 8 ; 67 \pm 15$ and $62 \pm 5$ beats/minute and the treatment group were $74 \pm 8 ; 63 \pm 9$ and $73 \pm 10$ beats/ minute respectively. The t-test analysis showed no significant difference $(p>0.05)$ between control and treatment cattle. Based on this study it can be concluded that healthy PO cattle 3rd-66th postpartum have a respiration rate of $21 \pm 6-29 \pm 5$ breaths/minute and a pulse rate of $62 \pm 5-82 \pm 8$ beats/minute, which can be used as a reference for healthy cattle, especially postpartum cattle.
\end{abstract}

Key words: Ongole Crossbreed Cattle; postpartum; Povidone iodine; pulse; respiration rate

\begin{abstract}
Abstrak
Penelitian ini bertujuan mengetahui frekuensi pulsus dan nafas saat recovery uterus sapi potong pasca beranak yang diinfusi Povidon iodine 1\%. Penelitian ini menggunakan 10 ekor sapi Peranakan Ongole (PO) yang beranak normal, sehat, umur 4-9 tahun, skor kondisi tubuh 2,5-3,5. Sapi dikelompokkan menjadi 2 yaitu 1). kontrol 2). infusi Povidon iodine 1\%. Semua sapi diperiksa secara fisik meliputi kondisi kesehatan umum, penghitungan frekuensi pulsus dan nafas pada hari ke-3 (minggu ke-1), hari ke 38 dan hari ke 66 pasca beranak. Sapi kelompok 2 diberi infusi Povidon iodine $1 \%$ sebanyak $250 \mathrm{ml}$ per-ekor pada hari ke-3. Hasil penelitian menunjukkan semua sapi dalam kondisi sehat dengan frekuensi nafas pada sapi kelompok kontrol hari ke-3, 38 dan 66 berturut-turut adalah $29 \pm 5 ; 24 \pm 0$ dan $25 \pm 4$ kali/menit dan pada sapi kelompok perlakuan adalah 28 $\pm 3 ; 22 \pm 4$ dan $21 \pm 6$ kali/menit. Frekuensi pulsus pada sapi kelompok kontrol hari ke-3, 38 dan 66 berturutturut adalah $82 \pm 8 ; 67 \pm 15$ dan $62 \pm 5 \mathrm{kali} /$ menit dan kelompok perlakuan adalah $74 \pm 8 ; 63 \pm 9$ dan $73 \pm 10$ kali/menit. Uji t-test didapatkan bahwa tidak ada perbedaan yang singifikan $(\mathrm{p}>0,05)$ antara sapi kontrol dan perlakukan. Berdasarkan hasil penelitian ini dapat disimpulkan bahwa sapi PO sehat 3-66 hari pasca beranak
\end{abstract}


mempunyai frekuensi nafas $21 \pm 6-29 \pm 5 \mathrm{kali} /$ menit dan frekuensi pulsus $62 \pm 5-82 \pm 8 \mathrm{kali} / \mathrm{menit}$, yang dapat dipakai sebagai acuan pada sapi sehat, khususnya sapi pasca beranak.

Kata kunci : nafas; pasca beranak; Povidone iodine; pulsus; Sapi PO

\section{Pendahuluan}

Sapi potong merupakan ternak ruminansia besar yang berperan sebagai komoditas unggulan, yang diharapkan dapat memenuhi kebutuhan daging dalam negeri melalui program swasembada daging dari Dirjen Peternakan dan Kesehatan Hewan, Kementrian Pertanian. Program tersebut telah berhasil meningkatkan populasi sapi potong manjadi 16,4 juta ekor pada tahun 2018 (peningkatan 0,02 \%) dibanding tahun 2017 (Anonim, 2010; Ariningsih, 2014; Anonim, 2019). Salah satu jenis sapi yang banyak mendukung program tersebut adalah sapi persilangan Ongole (PO). Sapi PO merupakan salah satu sapi lokal yang banyak dibudidayakan di Indonesia, karena daya tahan dan aktivitas reproduksi yang relatif lebih bagus dibanding sapi silangan lainnya. Walaupun demikian, kinerja reproduksi sapi PO masih perlu dioptimalkan, karena hasil penelitian menunjukkan bahwa service/conception (S/C) 1,97 $\pm 0,20$ dan bahkan masih banyak yang lebih dari 2 (Matondang dan Rudiana, 2014; Sudrajad dan Subiharta, 2014; Kusuma et al., 2017). Service/conception yang melebihi 1 tersebut dapat dipengaruhi oleh proses beranak dan proses involusi uterus. Saat beranak dan pasca beranak merupakan salah satu titik kritis dalam pemeliharaan sapi potong, karena saat setelah beranak, uterus sapi yang sebelumnya berisi fetus akan berubah ke arah normal seperti sebelum bunting. Uterus berubah menjadi lebih kecil, selsel serta jaringan yang rusak diperbaiki dan akan kembali pada kondisi normal setelah pengeluaran plasenta (Sheldon, 2007; Ismudiono et al., 2010; Saut et al., 2011).

Sesaat setelah beranak, sapi akan mengeluarkan lochia yang merupakan sisa-sisa cairan fetus, darah dari pembuluh darah umbilikus, karunkula dan selaput fetus yang mengalami nekrosis. Hari ke 2 dan 3 pasca beranak merupakan waktu pengeluaran lochia terbanyak. Pengeluaran lochia ini akan berkurang pada hari-hari berikutnya dan akan tuntas pada hari ke 14-18 pasca beranak (Crowe, 2008). Uterus yang tidak ada gangguan ataupun infeksi akan mengalami involusi berkisar 2 hingga 6 minggu. Adanya infeksi mikroorganisme pada uterus akan mengakibatkan terjadinya endometritis. Endometritis biasanya terjadi akibat masuknya bakteri patogen melalui vagina dan berlanjut ke serviks sehingga mengkontaminasi uterus selama partus. Endometritis ini akan membuat tertundanya involusi uterus dan menurunnya performa reproduksi, sehingga menyebabkan kerugian ekonomis (Sheldon, 2007; Dolezel et al., 2008; Ismudiono et al., 2010; Hadisutanto et al., 2013; Jeon et al., 2016; Sheldon dan Owens, 2017). Salah satu pengobatan untuk infeksi di dalam uterus sapi pasca beranak adalah pemberian antiseptik ataupun antibiotika. Antiseptik diberikan secara infusi langsung ke lumen uterus, yang ditujukan untuk membunuh bakteri, meningkatkan mekanisme pertahanan uterus atau meningkatkan tonus uteri dan aliran darah. Salah satu antiseptik yang sering digunakan adalah iodine yang bersifat bakterisidal, fungisidal, tuberculosidal, virusidal, dan sporisidal (Dolezel et al., 2008; Kumalajati, 2014; Ahmed dan Elsheikh, 2014). Pemberian infusi povidon iodin pada sapi pasca beranak akan meminimalkan terjadinya endometritis akibat infeksi bakteri, sehingga sapi akan tetap sehat.

Sapi yang menderita endometritis dapat menunjukkan gejala klinis peningkatan suhu tubuh, yang dapat berpengaruh terhadap frekuensi nafas dan pulsus (Jeon et al., 2016; Cunha et al., 2018). Gambaran proses fisiologis, termasuk frekuensi nafas dan pulsus merupakan kondisi yang dapat dipakai sebagai indikator status kesehatan hewan (Widiyono et al., 2003; Serang et al., 2016; Raharjo et al., 2019). Selama ini, referensi kondisi fisiologis yang digunakan untuk sapi PO pasca beranak kemungkinan kurang sesuai, karena masih mengacu pada referensi ras sapi lainnya dan bukan dalam kondisi pasca beranak. Hal ini dapat menyebabkan ketidak efektifan dalam tindakan diagnostik sehingga penanganan menjadi kurang akurat pada suatu kasus penyakit (Suherman 
et al., 2013; Rona et al., 2016; Serang et al., 2016). Penelitian ini bertujuan untuk mengetahui frekuensi pulsus dan nafas sapi PO pasca beranak dengan infusi Povidon $1 \%$ dan tanpa perlakuan, yang diharapakan hasilnya akan dapat dipakai sebagai acuan penentuan status kesehatan sapi secara klinis.

\section{Materi dan Metode}

Penelitian ini menggunakan 10 ekor sapi peranakan ongole (PO) pasca beranak, umur 4 9 tahun dengan skor kondisi tubuh 2,5-3,5 yang dipelihara secara semi intensif. Peralatan yang digunakan adalah stopwatch (Xiomi, China), glove (Minitub, Jerman), gun IB (Minitub, Jerman), plastic sheeth (Minitub, Jerman), gunting, spuit 50 cc, gelas ukur dan alat tulis. Bahan yang digunakan di dalam penelitian ini adalah aquadestilata (PT. USFA, Indonesia) dan Povidone iodine 1\% (Betadine-PT. Makam Beta Farma, Indonesia).

Sapi dikelompokkan menjadi 2 kelompok (masing-masing sejumlah 5 ekor) yaitu kelompok kontrol dan perlakuan infusi Povidon iodine 1\%. Semua sapi diperiksa kondisi fisik secara klinis, termasuk tingkah laku, nafsu makan. Pemeriksaan dilakukan sebelum melakukan pemeriksaan frekuensi nafas dan pulsus, pada sore hari jam 16.00. Selanjutnya dilakukan penghitungan frekuensi pulsus dan nafas pada semua sapi pada hari ke-3, 38 (minggu 5) dan 66 (minggu 9) pasca beranak. Sapi kelompok 2 diberikan larutan Povidon iodine $1 \%$ sebanyak $250 \mathrm{ml}$ perekor pada hari ke-3 pasca beranak secara intra uterine. Penghitungan frekuensi pulsus ditentukan dengan melakukan palpasi pada arteri cocygea-(Kelly 1984). Pengukuran frekuensi nafas dilakukan dengan meletakkan punggung tangan di depan hidung ternak dan menghitung hembusan nafas dalam 1 menit (Udeh et al., 2011). Hasil pengukuran frekuensi pulsus dan nafas dari 5 sapi sesuai kelompoknya dibuat rerata dan standar deviasinya dan dibandingkan dengan referensi sapi sehat. Perbandingan/perbedaan nilai rerata pengukuran frekuensi pulsus dan nafas antara sapi kontrol dan perlakuan pada hari yang sama (hari ke 3, 38 dan 66) selanjutnya dianalisa menggunakan t-test. Penelitian ini telah mendapat persetujuan etik dari Komite Etik Fakultas Kedokteran Hewan,
Universitas Gadjah Mada dengan nomor: 0134/ EC-FKH/Int/2019.

\section{Hasil dan Pembahasan}

Semua sapi yang dipakai di dalam penelitian ini mulai awal (hari ke 3 pasca beranak) sampai akhir (hari ke 66 pasca beranak) menunjukkan tingkah laku ceria, nafsu makan dan minum baik, tidak ada material abnormal yang keluar dari lubang alami, termasuk organ reproduksi, sehingga secara umum sapi yang digunakan di dalam penelitian ini dapat disimpulkan dalam kondisi sehat. Sapi penelitian ini juga menunjukkan tidak mengalami kesulitan pada saat bernafas, dan hal tersebut juga termanifestasi pada saat diperiksa dan dihitung frekuensi nafas dan pulsusnya. Hasil penghitungan frekuensi nafas pada sapi kelompok kontrol pada hari ke 3, 38 dan 66 pasca beranak berturut-turut adalah $29 \pm 5 ; 24 \pm 0$ dan $25 \pm 4$ kali/menit dan pada sapi kelompok perlakuan adalah $28 \pm 3 ; 22 \pm 4$ dan $21 \pm 6$ kali/menit (Tabel 1). Apabila dibandingkan dengan penelitian lain, hasil tersebut masih berada di dalam kisaran sapi sehat. Aritonang et al. (2017) melaporkan bahwa frekuensi nafas sapi sehat adalah antara 18-34 kali/ menit. Hasil penelitian ini sedikit lebih tinggi dari pada hasil penelitian Serang et al. (2016) pada sapi bali betina dewasa yang menndapatkan hasil penghitungan frekensi nafas antara 16,05 $\pm 0,82$ sampai $20,95 \pm 0,88$. Hasil penelitian yang sedikit lebih rendah dilaporkan oleh Ferreira et al. (2006) yaitu kisaran frekuensi nafas sapi adalah 24-36 kali/menit.

Tabel 1. Hasil penghitungan frekuensi nafas per menit pada sapi kelompok kontrol dan perlakuan infusi Povidon iodine $1 \%(\mathrm{n}=10)$

\begin{tabular}{lccc}
\hline Perlakuan & \multicolumn{3}{c}{ Hari ke (pasca beranak) } \\
& 3 & 38 & 66 \\
Kontrol $(\mathrm{n}=5)$ & $29 \pm 5^{\mathbf{a}^{*}}$ & $24 \pm 0^{\mathbf{b}^{*}}$ & $25 \pm 4^{\mathrm{c}^{+}}$ \\
Perlakuan $(\mathrm{n}=5)$ & $28 \pm 3^{\mathbf{a}^{*}}$ & $22 \pm 4^{\mathbf{b}^{*}}$ & $21 \pm 6^{\mathrm{c}^{*}}$ \\
\hline
\end{tabular}

* Ket: Nilai dengan huruf yang sama adalah nilai yang dibandingkan dan menunjukkan tidak berbeda nyata $(\mathrm{P}<0,05)$

Walaupun ada kecenderungan perbedaan frekuensi nafas antara sapi kontrol dan perlakuan, serta dari hari ke 3 ke hari ke 38 dan 66, tetapi secara fisik semua sapi dalam kondisi yang sehat. Perbedaan ini kemungkinan disebabkan oleh faktor lingkungan pada saat pemeriksaan, terutama suhu 
lingkungan yang tidak sama antara hari ke 3, 38 dan 66 pasca beranak. Beberapa faktor yang dapat mempengaruhi frekuensi pernafasan antara lain adalah kondisi kesehatan hewan, umur, ukuran tubuh, aktifitas fisik, status kebuntingan, adanya gangguan pada saluran pencernaan, pernafasan dan stres (Kelly, 1984; Feils dan Magee, 2018; Yanuartono et al., 2018a,b). Salah satu stress yang dapat terjadi adalah akibat pengaruh lingkungan, kondisi pasca beranak dan akibat interaksi dengan orang asing, terutama ketika akan diperiksa (Lima et al., 2018). Stres yang paling sering dialami oleh sapi adalah akibat perubahan lingkungan, terutama karena suhu dan kelembaban kandang. Suhu udara yang meningkat di atas suhu kritis akan menyebabkan sapi menderita cekaman panas, sehingga mekanisme termoregulasi mulai bekerja terutama dengan cara meningkatkan respirasi, detak jantung dan penguapan air melalui kulit. Secara fisiologis, peningkatan frekuensi respirasi terjadi karena adanya mekanisme pembuangan panas tubuh untuk menjaga suhu tubuh dan adanya peningkatan aktivitas metabolisme. Peningkatan frekuensi pernafasan dapat terjadi pada ternak dalam rangka menjaga keseimbangan panas tubuh saat mengalami perubahan panas tubuh dari hasil metabolisme pakan dan cuaca lingkungan. Secara umum suhu lingkungan akan meningkat pada siang hari dan menurun kembali pada sore hari, sehingga frekuensi nafas sapi pada siang hari akan lebih tinggi dibanding pada pagi atau sore hari. Suhu kandang harian di Indonesia umumnya tinggi yang berkisar antara $24-35{ }^{\circ} \mathrm{C}$ yang akan sangat mempengaruhi tingkat produktivitas sapi. Pemeliharaan dengan sistim dikandangkan ataupun sistim umbaran dengan banyak naungan akan sangat meminimalkan stress pada sapi dari panas lingkungan (Schutz et al., 2010; Suherman et al., 2013).

Perubahan frekuensi nafas pada sapi secara patologis dapat terjadi baik karena adanya gangguan paru-paru maupun organ lain. Tortorelli et al. (2017) melaporkan bahwa 18/28 (64\%) sapi yang terinfeksi Mycoplasma spp. pada saluran pernafasannya menunjukkan peningkatan frekuensi nafas diatas $40 \mathrm{kali} / \mathrm{menit}$. Peningkatan frekuensi nafas dapat diamati pada sapi yang mengalami kembung ataupun keracunan. Distensi rumen pada sapi kembung akan mendesak diafragma dan rongga dada, sehingga menyebabkan sapi kesulitan bernafas (Ramaswamy dan Sharma, 2011; Yanuartono et al., 2018b). Pemberian urea yang belebihan dapat menyebabkan keracunan, yang salah satu gejala klinisnya adalah adanya peningkatan frekuensi nafas (Shaikat et al., 2012; Yanuartono et al., 2018a). Pada penelitian ini semua sampel sapi yang dipakai tidak menunjukkan adanya gangguan yang berkaitan dengan pernafasan, baik yang disebabkan gangguan pada saluran pernafasan, organ lain maupun organ reproduksi akibat dampak pasca beranak.

Sistem sirkulasi berhubungan erat dengan paru-paru tempat terjadi pertukaran gas oksigen dan karbon dioksida, sehingga frekuensi nafas dan pulsus akan berkaitan. Secara fisiologis nafas dan pulsus akan meningkat apabila sapi melakukan aktivitas/exercise (Aengwanich et al., 2011; Feils dan Magee, 2018). Sejalan dengan pemeriksaan frekuensi nafas, hasil penghitungan frekuensi pulsus pada penelitian ini juga berada di dalam kisaran sapi sehat. Penghitungan frekuensi pulsus pada kelompok kontrol pada hari ke-3, 38 dan 66 berturut-turut adalah $82 \pm 8 ; 67 \pm 15$ dan 62 $\pm 5 \mathrm{kali} / \mathrm{menit}$ dan kelompok perlakuan adalah $74 \pm 8 ; 63 \pm 9$ dan $73 \pm 10 \mathrm{kali} /$ menit (Tabel 2). Hasil tersebut sesuai dengan beberapa referensi, yang menyebutkan bahwa sapi sehat mempunyai frekuensi pulsus antara 40 sampai $70 \mathrm{kali} / \mathrm{menit}$ (John et al., 2013) dan antara 46-84 kali/menit (Sudrajad dan Adiarto, 2012). Sapi bali juga mermpunyai frekuensi pulsus yang hampir sama dengan penelitian ini, yaitu $67,40 \pm 8,41 \mathrm{kali} /$ menit untuk sapi dara dan 76,66 $\pm 7,88 \mathrm{kali} /$ menit untuk sapi bunting (Madu et al., 2015; Jinorati et al., 2016; Rona et al., 2016).

Tabel 2. Hasil penghitungan frekuensi pulsus (per menit) pada sapi kelompok kontrol dan perlakuan infusi Povidon iodine $1 \%(\mathrm{n}=10)$.

\begin{tabular}{lccc}
\hline Perlakuan & \multicolumn{3}{c}{ Hari ke (pasca beranak) } \\
& 3 & 38 & 66 \\
Kontrol $(\mathrm{n}=5)$ & $82 \pm 8^{\mathrm{a} *}$ & $67 \pm 15^{\mathrm{b} *}$ & $62 \pm 5^{\mathrm{c} *}$ \\
Perlakuan $(\mathrm{n}=5)$ & $74 \pm 8^{\mathrm{a} *}$ & $63 \pm 9^{\mathrm{b} *}$ & $73 \pm 10^{\mathrm{c} *}$ \\
\hline
\end{tabular}

* Ket: Nilai dengan huruf yang sama adalah nilai yang dibandingkan dan menunjukkan tidak berbeda nyata $(\mathrm{P}<0,05)$

Seperti pada frekuensi nafas, variasi dan perubahan frekuensi pulsus dapat disebabkan karena adanya aktivitas fisik, penyakit ataupun 
stress. Penurunan output jantung yang parah secara drastis akan menurunkan tekanan darah, menimbulkan respons yang kuat oleh refleks baroreseptor, sehingga denyut jantung akan meningkat. Sebaliknya penurunan output jantung dan vasokonstriksi perifer yang intens akan menyebabkan melemahnya pulsus (Feils dan Magee, 2018). Stres akibat paparan peningkatan suhu lingkungan juga akan meningkatkan frekuensi pulsus. Palulungan et al. (2013) melaporkan bahwa penambahan suhu kandang akan meningkatkan frekuensi pulsus dan nafas sapi Friesian Holland (FH). Hal serupa juga dilaporkan oleh Aengwanich et al. (2011) yaitu frekuensi nafas dan pulsus akan menjadi lebih tinggi pada sapi yang berada langsung terkena sinar matahari dibanding yang berada di tempat teduh. Suherman et al. (2013) juga mendapatkan frekensi pulsus meningkat dan lebih tinggi pada sapi FH di Jakarta dibanding di daerah Bogor yang suhu lingkungannya lebih rendah. Hasil penelitian Rona et al. (2016) menunjukkan bahwa sapi bali bunting trismester II mempunyai frekuensi paling tinggi pada siang hari dibanding pagi dan sore hari.

Perubahan frekuensi pulsus pada sapi secara patologis dapat terjadi terutama karena adanya gangguan jantung, paru-paru antara lain pneumonia, gagal jantung dan pericarditis (Buczinski et al., 2010). Tortorelli et al. (2017) melaporkan bahwa selain adanya kenaikan frekuensi nafas sebesar 64\% (18/28) ekor, sebanyak 79\% (22/28) ekor sapi yang terinfeksi Mycoplasma spp. pada saluran pernafasannya, juga menunjukkan peningkatan frekuensi pulsus diatas $100 \mathrm{kali} /$ menit. Hal ini menunjukkan adanya keterkaitan antara frekuensi nafas dan frekuensi pulsus, sehingga kedua parameter tersebut perlu diperiksa sebagai satu kesatuan pada saat memeriksa kondisi kesehatan sapi. Berdasarkan frekuensi pulsus pada penelitian ini semua sampel sapi yang dipakai tidak menunjukkan adanya gangguan yang berkaitan dengan pernafasan ataupun jantung, baik yang disebabkan gangguan pada saluran pernafasan, jantung maupun dampak pasca beranak.

Sapi yang dipakai di dalam penelitian ini dipelihara di dalam kandang, dan pemeriksaan frekuensi nafas serta pulsus dilakukan pada sore hari sekitar jam 16.00, sehingga stress akibat suhu lingkungan dapat diminimalkan. Konfirmasi kemungkinan adanya stres dapat dilakukan antara lain dengan melihat gambaran hematologi, kimia darah dan melihat kadar hormon kortisol (Sarmin et al., 2014; 2019). Hasil analisa perbandingan dengan uji statistik t-test pada sapi kontrol dan perlakuan pada hari yang sama (hari ke 3, 38 dan 66 pasca bernak) didapatkan tidak adanya perbedaan secara nyata $(\mathrm{P}>0,05)$ pada frekuensi nafas dan pulsus antara sapi kelompok kontrol dan perlakuan infusi Povidone iodine 1\%. Hasil analisa perbandingan tersebut, dan didukung dengan hasil pemeriksaan klinis, mengindikasikan bahwa sapi yang dipakai di dalam penelitian ini (sapi kontrol dan perlakuan) dalam kondisi yang sehat, tidak ada gangguan reproduksi pasca beranak. Hal ini menunjukkan bahwa frekuensi nafas $21 \pm 6-29$ $\pm 5 \mathrm{kali} /$ menit dan frekuensi pulsus $62 \pm 5-82$ $\pm 8 \mathrm{kali} / \mathrm{menit}$ dapat dipakai sebagai acuan untuk interpretasi kesehatan sapi PO, khususnya untuk sapi pasca beranak sampai hari 66 (minggu ke 5).

\section{Kesimpulan}

Frekuensi pulsus dan nafas sapi PO pasca beranak pada sapi kelompok kontrol dan infusi Povidone iodine $1 \%$ tidak ada perbedaan, yang mengindikasikan semua sapi dalam kondisi yang sehat. Kisaran frekensi nafas sapi PO 3 - 66 hari pasca beranak adalah $21 \pm 6-29 \pm 5 \mathrm{kali} / \mathrm{menit}$ dan frekuensi pulsus $62 \pm 5-82 \pm 8 \mathrm{kali} / \mathrm{menit}$ dapat dipakai sebagai acuan pada sapi sehat, khususnya sapi pasca beranak. Infusi Povidone iodine $1 \%$ disarankan akan lebih baik diberikan pada sapi pasca beranak yang menunjukkan kemungkinan adanya infeksi mikroorganisme.

\section{Ucapan Terima Kasih}

Terima kasih penulis ucapkan kepada Kementerian Pertanian atas beasiswa S2 yang telah diberikan.

\section{Daftar Pustaka}

Aengwanich, W., Kongbuntad, W., and Boonsorn, T. (2011) Effects of shade on physiological changes, oxidative stress, and total antioxidant power in Thai Brahman cattle. Int J Biometeorol. 55, 741-748. 
Ahmed, F.O., and Elsheikh, A.S. (2014). Treatment of Repeat Breeding in Dairy Cows with Lugol's Iodine. IOSR-JAVS. 7 (4-1): 22-26.

Anonim. (2010). Blue Print Program Swasembada Daging Sapi Tahun 2014. Ditjen Peternakan dan Kesehatan Hewan. Jakarta.

Anonim. (2019). Statistik peternakan dan Kesehatan Hewan tahun 2019. Ditjennak Peternakan dan Keswan . Kementerian pertanian.

Ariningsih, E. (2014). Kinerja Kebijakan Swasembada Daging Sapi Nasional. Forum Penelitian Agro Ekonomi. 32 (2): 137-156.

Aritonang, S.B., Yuniarti, R., Abinawanto, Imron, I., and Bowolaksono, A. (2017). Physiology Response of Indigenous Cattle Breeds to the Environment in West Sumbawa Indonesia. American Inst of Physics. 1862 : 1-4.

Buczinski, S., Francoz, D., Fecteau, G., and DiFruscia, R. (2010). Heart Disease in Cattle with Clinical Signs of Heart Failure: 59 Cases. Can Vet J. 51:1123-1129.

Crowe, M.A. (2008). Resumption Of Ovarian Cyclicity In Pasca beranak Beef And Dairy Cows. Reprod. Dom. Anim. 43(5):20-28.

Cunha, F., Jeon, S.J., Daetz, R., Vieira-Neto, A., Laporta, J., Jeong, K.C, Barbet, A.F., Risco, C.A., and Galvão, K.N. (2018). Quantifying known and emerging uterine pathogens, and evaluating their association with metritis and fever in dairy cows. Theriogenology. 114: 25-33.

Dolezel, R., Vecera, M., Palenik, T., Cech, S., and Vyskocyl, M. (2008). Systematic Clinical Examination of Early Postpartus Cows and Treatment of Puerperal Endometritis Did Not Have Any Beneficial Effect on Subsequent Reproductives Performance. Vet Med. 53 (2):59-69.

Feils, D., and Magee, C. (2018). Anatomy and physiology of farm animals. John Wiley \& Sons, Inc.

Ferreira, F., Pires, M.F., Martinez, M.L., Coelho, S.G., Carvalho, A.U., Ferreira, P. M., Facury, Filho, E.J., and Campos, W.E. (2006). Parâmetros Fisiológicos de Bovines Cruzados Submetidos ao Estresse Calórico. Arq Bras Med Vet Zootec. 58 (5):732-738.
Hadisutanto, B., Purwantara, B., and Darodjah, S. (2013).Involusi Uteri dan Waktu Estrus pada Induk Sapi Perah FH Pasca Partus. Jurnal Ilmu Ternak. 13 (1): 4-7.

Ismudiono, Srianto, P., Anwar, H., Madyawati, S.P., Samik, A., and Safitri, E. (2010). Buku Ajar Fisiologi Reproduksi pada Ternak. Surabaya: Airlangga University Press.

Jeon, S.J., Cunha, F., Ma, X., Martinez, N., VieiraNeto, A., Daetz, R., Bicalho, R.C., Lima, S., Santos, J.E., Jeong, K.C., and Galvão, K.N. (2016) Uterine Microbiota and Immune Parameters Associated with Fever in Dairy Cows with Metritis. PLoS One. 1;11 (11): e0165740.

Jinorati, K.Y., Suartha, .IN., and Gunata, I.K. (2016). Frekuensi Pulsus Sapi Bali Pada Masa Kebuntingan Trimester Pertama di Sentra Pembibitan Sapi Bali, Desa Sobangan, Mengwi Badung. Buletin Veteriner Udayana. 8 ( 2): 117-121.

John, S.D., Christian, O.N.I., Olajide, O., Olusiji, F.S., Matthew, A.A., Mathew, W., David O.O., Abuba, T.M.S., Babatunde, A.O., Raman, A.L., Adeyemi, S.A. and Samuel, A.A. (2013). Effects of Coat Colour Genes on Body Measurements, Heat Tolerance Traits and Haematological Parameters in West African Dwarf Sheep. Genetics. 3: 280-284.

Kelly, W.B. (1984). Veterinary Clinical Diagnosis. 3rdEdition.London:The Williams and Wilkins Company. 318-327.

Kumalajati, A. (2014). Infusi Iodium Povidon 2\% Intra Uterus pada Sapi Perah dan Sapi Potong Penderita Endometritis: Kajian pada Kadar Estrogen, Kualitas Estrus dan Kebuntingan Pasca Inseminasi Buatan. Thesis. Fakultas Kedokteran Hewan Universitas Gadjah Mada, Yogyakarta.

Kusuma, S.B., Ngadiyono, N., and Sumadi. (2017). Buletin Peternakan. Estimasi Dinamika Populasi Dan Penampilan Reproduksi Sapi Peranakan Ongole Di Kabupaten Kebumen Provinsi Jawa Tengah . Buletin Peternakan. 41(3): 230-242. 
Lima, M.L.P., Negrão, J.A., de Paz, C.C.P., and Grandin, T. (2018). Minor Corral Changes and Adoption of Good Handling Practices Can Improve the Behavior and Reduce Cortisol Release in Nellore Cows.Trop Anim Health Prod. 50: 525-530.

Madu, E.Y., Suartha, I,N, and Batan, I.W. (2015). Status Praesen Sapi Bali Dara. Indonesia Medicus Veterinus. 4 (5) : 437-444.

Matondang, R.H., and Rusdiana, S. (2014). Langkah-Langkah Strategis dalam Mencapai Swasembada Daging Sapi/ Kerbau 2014. J. Litbang Pert. 32 (3):131139.

Palulungan, J.A., Adiarto, Hartatik, T. (2013). Pengaruh kombinasi pengkabutan dan kipas angin terhadap kondisi fisiologis sapi perah peranakan friesian holland. Buletin Peternakan. 37 (3): 189-197.

Raharjo, S., Hartati S., Indarjulianto, S., and Widayanti R. (2019). Studi Frekuensi Nafas dan Pulsus pada Ular Sanca Batik (Malayopython Reticulatus) Lokalitas Jawa. J sains veteriner. 37 (1): 121-127.

Ramaswamy, V., and Sharma, R.H. (2011). Plastic bags threat to environment and cattle health: A retrospective study from Gondar city, Ethiopia. Special Issue IIOAB J. 2 (1): 7-12.

Rona, T.L., Suartha, I.N., and Budiasa, M.K. (2016). Frekuensi detak jantung sapi bali betina pada kebuntingan trimester ke II. Buletin Veteriner Udayana. 8 (2): 106-111.

Sarmin, Hana, A., Astuti, P., Fibrianto, Y.H., and Mona Airin, C. (2014). Kajian kadar kortisol sapi yang dipotong di rumah potong hewan Yogyakarta. Jurnal Kedokteran Hewan. 8 (2): 134-137.

Sarmin, Hana, A., Astuti, P., Fibrianto, Y.H., and Mona Airin, C. (2019). Respons Hematologi dan Kimia Darah Domba Lokal Indonesia Terhadap Stres Transportasi Selama 12 Jam. J Vet. 20 (1) : 48 -57.

Saut, J.P.E., Oliviera, R.S.B.R., Martins, C.F.G., Moura, A.R.F., Tsuruta, S.A., Nasciutti, N.R., Santos, R.M., and Headley, S.A.
(2011). Clinical Observations of Postpartum Uterine Involutionin Crossbreed Dairy Cow. Vet Not. $17(1): 16-25$.

Schutz, K.E., Rogers, A.R., Poulouin, Y.A., Cox, N.R., and Tucker, C.B. (2010). The amount of shade influences the behavior and physiology of dairy cattle. Journal of Dairy Science.93 (1):125-133.

Serang, P.M., Suartha, I.N., and Arjentinia, I.P.G.Y. (2016). Frekuensi Respirasi Sapi Bali Betina Dewasa Di Sentra Pembibitan Sapi Bali Desa Sobangan, Kecamatan Mengawi, Kabupaten Badung. Buletin Veteriner Udayana. 8 (1): 25-29.

Shaikat, A.H., Hassan, M.M., Azizul Islam, S.K.M., Khan, S.A., Hoque, A., Is-lam, N. and Hossain, M.B. (2012). Non-protein nitrogen compound poisoning in cattle. Univ. j. zool. Rajshahi Univ. 31: 65-68.

Sheldon, M. (2007). Endometritis in Cattle: Pathogenesis Concequences for Fertility, Diagnosis and Therapeutic Recomemndations. Reproduction Management Bulletin (Intervet). 2(1):1-5.

Sheldon, I.M., and Owens, S.E. (2017). Postpartum uterine infection and endometritis in dairy cattle. Anim Reprod, 14 (3):.622-629.

Sudrajad, P., and Adiarto. (2012). Pengaruh Stress Panas Terhadap Performa Produksi Susu Sapi Friesian Holstein di Balai Besar Pembibitan Ternak Unggul Sapi Perah Baturraden. Di dalam: Prasetyo, L.H., Damayanti, R., Iskandar, S., Herawati, T., Priyanto, D., Puastuti, W., Anggraeni, A., Tarigan, S., Wardhana, A.H., editor. Seminar Nasional Teknologi Peternakan dan Veteriner. Bogor: Pusat Penelitian dan Pengembangan Peternakan. 7-8: 341-346.

Sudrajad, P., and Subiharta. (2014). Karakter Fenotipik Sapi Betina Peranakan Ongole (PO) Kebumen. Widyariset.17 (2), 283-290.

Suherman, D., Purwanto, B.P., Manalu, W., and Permana, I.G. (2013). Simulasi Artificial Neural Network untuk Menentukan Suhu Kritis pada Sapi Fries Holland Berdasarkan Respon Fisiologis. JITV. 18 (1): 70-80. 
Tortorelli, G., Carrillo Gaeta, N., Mendonça Ribeiro, B.L., Miranda Marques, L., Timenetsky, J., and Gregory, L. (2017). Evaluation of Mollicutes Microorganisms in Respiratory Disease of Cattle and Their Relationship to Clinical Signs. J. Vet. Intern. Med. 31(4), 1215-1220.

Udeh, I.P.O. Akporhuarho, C.O., and Onogbe. (2011). Phenotypic Correlations Among Body Measurements and Physiological Parameters in Muturu and Zebu Cattle. ARPN-J Agric Biol Sci.6 (4): 1-4.

Widiyono, I, Wuryastuti, H., Indarjulianto, S., and Purnamaningsih, H. (2003). Frekuensi Nafas, Pulsus dan gerak rumen serta suhu tubuh pada kambing peranakkan Ettawa selama 3 bulan pertama kehidupan pasca lahir. J Sain Vet. 21 (2): 39-42
Yanuartono, Indarjulianto, S., Nururrozi, A., Purnamaningsih, H., and Raharjo, S. (2018) a. Review: Peran pakan pada kejadian kembung rumen. JIIP.28 (2): 141-157

Yanuartono, Nururrozi, A., Indarjulianto, S., Purnamaningsih, H., and Raharjo, S. (2018) b. Urea: Manfaat pada ruminansia. JIIP. 28 (1): $10-34$ 